\title{
Unusual presentation of Paget's disease of bone
}

\author{
Samantha Sathyakumar, ${ }^{1}$ Nitin Kapoor, ${ }^{2}$ Julie Hephzibah, ${ }^{3}$ Thomas Vizhalil Paul ${ }^{2}$
}

'Department of Endocrinology, Diabetes Metabolism, Christian Medical College, Vellore, Tamil Nadu, India

${ }^{2}$ Christian Medical College, Vellore, Tamil Nadu, India ${ }^{3}$ Department of Nuclear Medicine, Christian Medical College, Vellore, Tamil Nadu, India

\section{Correspondence to}

Professor Thomas Vizhalil Paul, thomasvpaul@yahoo.com

Accepted 18 February 2016

\section{DESCRIPTION}

A 60-year-old man presented with sudden onset of ptosis of the right eye. There was no history of headache, fever, altered sensorium, vision loss, trauma, diabetes or weakness of the limbs. On examination, there was right-sided third nerve palsy (figure 1). The rest of the neurological and systemic examination was normal. The patient's brain MRI was normal apart from pagetoid bony changes as evidenced by large well-defined lytic and sclerotic lesions in the skull along with diploic widening.

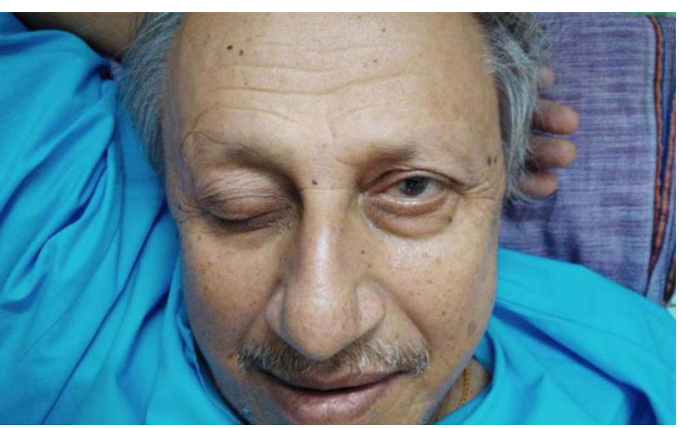

Figure 1 Face of the patient showing ptosis of the right eye.
Blood investigations were normal except for markedly elevated alkaline phosphatase of $2171 \mu / \mathrm{L}$ (normal 40-125). The patient's skull X-ray revealed both osteolysis and osteosclerosis. His technetium bone scan showed marked uptake in the skull and left hip suggestive of polyostotic Paget's disease of bone (PDB; figure 2A). He was treated with yearly zoledronic acid. He had complete resolution of his neurological deficit within 2 months with a significant decline in the alkaline phosphatase $(1567 \mu / \mathrm{L})$. At 2-year follow-up, his alkaline phosphatase was normal $(84 \mu / \mathrm{L})$ and bone scan showed a marked regression of the disease (figure $2 \mathrm{~B}$ ).

PDB is a disease of osteoclasts where there are areas of marked bone resorption followed by abnormal new bone formation. It usually presents after the age of 55 years and the highest prevalence has been reported from the UK. The SQSTM1 (sequestosome-1 encoder) gene has been shown to be associated with this disease. ${ }^{1}$ Bone pain, deformities, fractures and neurological complications such as headache, hearing loss and nerve palsies have been reported as the manifestations of PDB. The skull and pelvis are usually involved. ${ }^{2}$ Third nerve palsy is a rare presentation of this disease and is due to the compression of the nerve as it enters the superior orbital fissure. ${ }^{3}$ Diagnosis is usually established by finding marked elevation of alkaline phosphatase, bone scan showing marked uptake in the
A

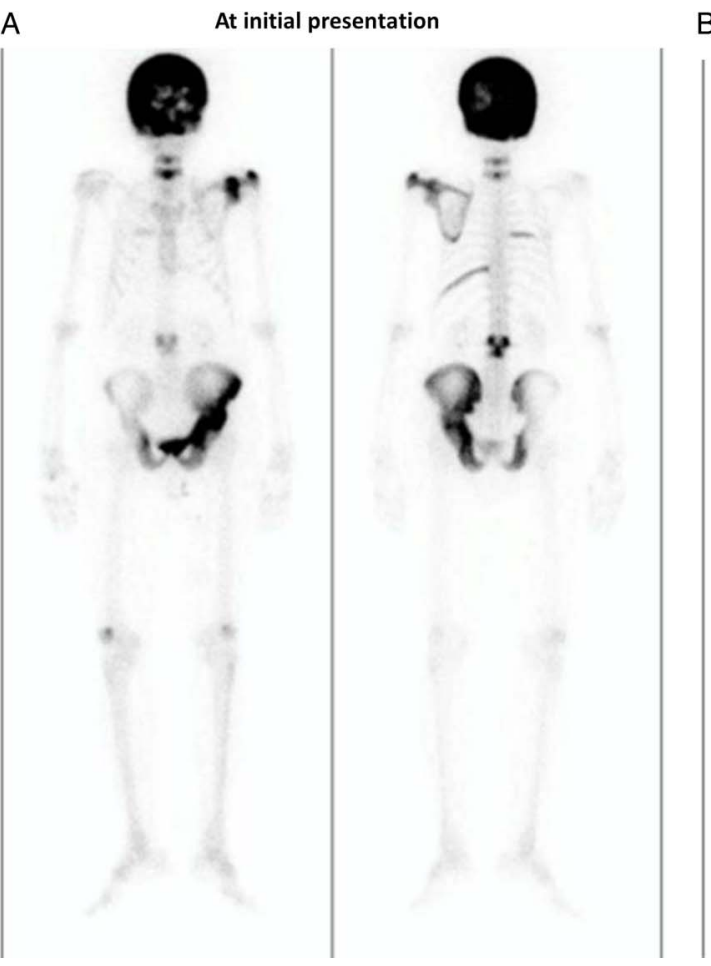

B

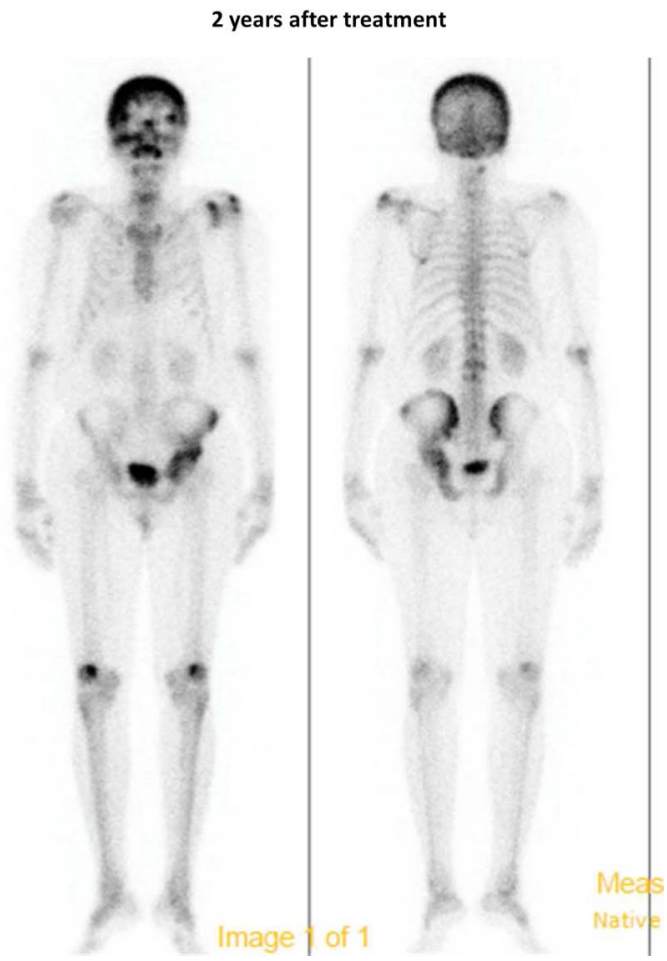


affected bones and X-ray showing both osteosclerosis and osteolysis. Treatment of this disease includes establishing adequate

\section{Learning points}

- Bone pains, deformities, fractures and neurological complications such as headache, hearing loss and nerve compression syndromes resulting in nerve palsies may be the initial presentation of Paget's disease of bone.

- Management of this condition usually involves maintaining adequate calcium and vitamin D nutrition and using antiresorptive agents such as zoledronic acid. calcium and vitamin D nutrition and using antiresorptive agents such as zoledronic acid. ${ }^{1}$

Acknowledgements The authors thank Ms Banu Shankar for secretarial help.

Contributors SS and NK wrote the manuscript. JH and TVP reviewed the manuscript. SS, NK, JH and TVP approved the final manuscript.

Competing interests None declared.

Patient consent Obtained.

Provenance and peer review Not commissioned; externally peer reviewed.

\section{REFERENCES}

1 Tan A, Ralston SH. Paget's disease of bone. QJM 2014;107:865-9.

2 Griz L, Fontan D, Mesquita P, et al, Brazilian Society of Endocrinology and Metabolism. Diagnosis and management of Paget's disease of bone. Arq Bras Endocrinol Metabol 2014;58:587-99.

3 Poncelet A. The neurologic complications of Paget's disease. J Bone Miner Res 1999;14:88-91.

Copyright 2016 BMJ Publishing Group. All rights reserved. For permission to reuse any of this content visit http://group.bmj.com/group/rights-licensing/permissions.

BMJ Case Report Fellows may re-use this article for personal use and teaching without any further permission.

Become a Fellow of BMJ Case Reports today and you can:

- Submit as many cases as you like

- Enjoy fast sympathetic peer review and rapid publication of accepted articles

- Access all the published articles

- Re-use any of the published material for personal use and teaching without further permission

For information on Institutional Fellowships contact consortiasales@bmjgroup.com

Visit casereports.bmj.com for more articles like this and to become a Fellow 